\title{
PROGRAM KEMITRAAN MASYARAKAT (PKM) PENGEMBANGAN PEMBELAJARAN BERBASIS KONTEKSTUAL PADA GURU IPS DI KOTA TOMOHON
}

\author{
Manuel Estevanus Korompis, Paulus Robert Tuerah \\ Universitas Negeri Manado \\ vidikorompis@gmail.com, paulustuerah@unima.ac.id
}

\begin{abstract}
Abstrak
Tujuan dari pengabdian ini adalah: (1) Merancang pembelajaran IPS berbasis Metode pembelajaran Kontekstual; (2 )Penggunaan Metode Kontekstual sebagai media dalam pembelajaran IPS, dan; (3) Peningkatan kompetensi guru IPS di Tomohon dalam pembelajaran menggunakan Metode Kontekstual. Metode yang digunakan dalam pengabdian ini adalah metode perencanaan dan pelaksanaan pengembangan pembelajaran berbasis kontekstual, berlangsung di Kota Tomohon, hasil yang didapatkan adalah bahwa; (1) adanya peningkatan pengetahuan dan keterampilan para guru tentang pengembangan metode pembelajaran kontekstual walaupun awalnya ditemukan bahwa masih sedikit guru IPS yang mengimplementasikannya; (2) Tersedianya media metode pembelajran kontekstual
\end{abstract}

\section{Kata Kunci: Kontekstual, Tomohon, Pengembangan}

\section{PENDAHULUAN}

\section{Analisi Situasi}

Masih rendahnya mutu lulusan

mengharuskan lembaga pendidikan di tuntut untuk meningkatkan mutu lulusan dan layanan lembaga pendidikan karena semakin ketatnya persaingan dalam lapangan kerja. Salah satu implikasi globalisasi dalam pendidikan yaitu adanya deregulasi yang memungkinkan peluang lembaga pendidikan asing membuka sekolahnya di Indonesia. Oleh karena itu persaingan antar lembaga penyelenggara pendidikan dan pasar kerja akan semakin berat. Mengantisipasi perubahan-perubahan yang begitu cepat serta tantangan yang semakin besar dan kompleks, tiada jalan lain bagi lembaga pendidikan kecuali hanya mengupayakan segala cara untuk meningkatkan daya saing lulusan serta produk-produk akademik dan layanan lainnya, yang antara lain dicapai melalui peningkatan mutu Pendidikan [2].

$$
\text { Banyak guru yang masih belum }
$$
memahami berbagai model pembelajaran yang merupakan strategi dalam menyampaikan materi berbagai bidang ilmu pengetahuan di dalam mengkonstruk pengetahuan siswa. Guru yang professional dituntut untuk mampu mengembangkan pendekatan model pembelajaran, baik teoritik maupun praktek, yang meliputi aspek-espek, konsep, prinsip, dan teknik. Memilih model pembelajaran yang tepat merupakan persyaratan untuk membantu siswa dalam rangka meningkatkkan mutu pembelajaran. 
Guru merupakan aktor penting yang besar pengaruhya terhadap proses dan hasil belajar, bahkan sangat menentukan berhasil tidaknya peserta didik dalam belajar. Tugas guru tidak hanya menyampaikan informasi kepada peserta didik, tetapi harus dilatih sebagai fasilitator yang bertugas dalam memberikan kemudahan belajar (facilitate of learning) kepada seluruh peserta didik, agar mereka dapat belajar dalam suasana yang menyenangkan, gembira, penuh semangat, tidak cemas, dan terbuka

Rendahnya kemampuan guru dalam mengemas dan melaksanakan proses belajar mengajar menjadi penyebab rendahnya kualitas proses pembelajaran di sekolah. Salah satu faktor keberhasilan pembelajaran sangat tergantung dari kemampuan seorang pengajar atau guru dalam melaksanakan atau mengemas proses pembelajaran sehingga menghasilkan sesuatu yang sesuai dengan apa yang diinginkan pada tujuan pendidikan.

Banyak guru yang masih belum memahami berbagai model pembelajaran yang merupakan strategi dalam menyampaikan materi berbagai bidang ilmu pengetahuan di dalam mengkonstruk pengetahuan siswa. Guru yang professional dituntut untuk mampu mengembangkan pendekatan model pembelajaran, baik teoritik maupun praktek, yang meliputi aspek-espek, konsep, prinsip, dan teknik. Memilih model pembelajaran yang tepat merupakan persyaratan untuk membantu siswa dalam rangka meningkatkkan mutu pembelajaran

Rendahnya penguasaan model pembelajaran oleh seorang guru akan mempengaruhi keberhasilan peserta didik dalam pembelajaran. Seorang guru diharapkan mempunyai kemampuan untuk memilih model pembelajaran yang tepat sesuai dengan karakteristik anak dan karakteristik matapelajaran. Seperti ditulis dalam Hanafia yaitu [3]:

Tidak ada model pembelajaran yang paling efektif untuk semua mata pelajaran atau untuk semua materi. Di dalam Pemilihan model pembelajaran untuk diterapkan guru di dalam kelas mempertimbangkan beberapa hal: 1) tujuan pembelajaran, 2) sifat materi pelajaran, 3) ketersediaan fasilitas, 4) kondisi peserta didik, 5) alokasi waktu yang tersedia.

Rendahnya frekwensi guru dalam penggunaan model pembelajaran kooperatif learning. Seharusnya guru lebih banyak menggunakan model pembelajaran kooperatif yaitu rangkaian kegiatan belajar yang dilakukan oleh siswa dalam kelompokkelompok tertentu untuk mencapai tujuan pembelajaran yang telah dirumuskan. Sanjaya mengemukakan bahwa ada 4 unsur yang penting dalam model kooperatif yaitu: 1) ada peserta dalam kelompok, 2) adanya aturan kelompok, 3) adanya upaya belajar setiap anggota kelompok, 4) adanya tujuan yang harus dicapai [4]. 
Banyak guru matapelajaran IPS masih jarang atau belum optimal dalam menggunakan model pembelajaran Contextual Teaching Learning (CTL). Pembelajaran CTL merupakan salah satu model yang saat ini sering digunakan dalam proses kegiatan pembelajaran. Pembelajaran CTL merupakan model yang menekankan pada hubungan antara materi yang diajarkan dengan keadaan kehidupan nyata siswa [4].

Pembelajaran IPS khususnya di beberapa sekolah di Tomohon selama ini kurang menarik diajarkan pada siswa. Hal tersebut dipengaruhi oleh faktor-faktor diantaranya: (1) materi pelajaran IPS banyak berisi konsep abstrak yang sulit dipahami siswa. (2) Penyampaian materi IPS dengan metode ceramah nampaknya kurang optimal dalam meningkatkan aktivitas, minat dan motivasi belajar siswa. (3) Pembelajaran masih kurang mengaitkan IPS dengan kehidupan sehari-hari siswa. Kondisi tersebut menyebabkan kebosanan, perhatian, minat dan motivasi siswa dalam pembelajaran menjadi rendah. Pembelajaran yang berorientasi berpusat pada guru akan membatasi perkembangan kemampuan berpikir siswa. Rendahnya aktivitas, minat dan motivasi belajar siswa disebabkan adanya anggapan bahwa IPS merupakan ilmu yang memiliki sifat abstrak dan terlalu monoton. Untuk itu guru perlu melakukan pembelajaran IPS melalui kegiatan yang kreatif dan inovatif agar siswa memahami bahwa IPS adalah ilmu yang terkait dengan kehidupan manusia sehari-hari.

Salah satu jenis pembelajaran untuk menumbuhkan kesadaran terhadap matematika sebagai ilmu yang terkait dengan kehidupan sehari-hari dan diperkirakan dapat meningkatkan kemampuan berpikir kritis siswa adalah dengan pendekatan kontekstual atau Contextual Teaching and Learning (CTL). Pendekatan CTL (Contextual Teaching and Learning) yakni sebuah sistem belajar yang didasarkan pada filosofi bahwa seorang pembelajar akan mau dan mampu menyerap materi pelajaran jika mereka mampu menyerap makna pelajaran tersebut. Pendekatan CTL pada pembelajaran akan membantu siswa dalam membuat hubunganhubungan antara materi pelajaran dengan kehidupan nyata sehingga siswa akan mendapatkan makna dari apa yang dipelajarinya dan dapat mengembangkan kemampuan berpikir yang pada akhirnya menumbuh-kembangkan karakter siswa. Pendekatan kontekstual melibatkan tujuh komponen utama pembelajaran, yaitu konstruktivisme, bertanya, menemukan, masyarakat belajar, pemodelan, refleksi, dan penilaian otentik [5].

Mengimplementasikan pendekatan kontekstual dalam kegiatan pembelajaran berarti mengimplementasikan ketujuh komponen utama tersebut dalam kegiatan 
Jurnal ABDIMAS, Vol. 13, No. 1, April 2020

ISSN: 1979-0953 | e-ISSN: 2598-6066

pembelajaran. Dengan demikian, menyusun rencana pembelajaran dengan pendekatan kontekstual berarti merancang kegiatan pembelajaran yang mengakomodasi 7 komponen utama pembelajaran kontekstual tersebut. Rencana pembelajaran yang demikian selanjutnya kita sebut rencana pembelajaran berbasis kontekstual. Dalam pembelajaran kontekstual, rencana pembelajaran lebih diartikan sebagai rencana kegiatan guru, yang berupa skenario pembelajaran tahap demi tahap mengenai halhal yang akan dilakukakan guru IPS di Tomohon bersama siswa terkait topik yang akan dipelajari siswa demi mencapai kompetensi dasar yang telah ditentukan.

\section{PERMASALAHAN MITRA}

1. Kurangnya pemahaman, penguasaan, dan terampil dalam merancang metode pembelajaran kontekstual.

2. Kurangnya pemahaman guru IPS di Tomohon dalam membuat instrumen penelitian.

3. Kurangnaya pemahaman guru IPS di Tomohon dalam Penggunaan metode kontekstual dalam pembelajaran.

\section{TARGET DAN LUARAN}

\section{Luaran dan Target Capaian}

Rencana Luaran
1. Merancang pembelajaran IPS berbasis Metode pembelajaran Kontekstual

2. Penggunaan Metode Kontekstual sebagai media dalam pembelajaran IPS, dan

3. Peningkatan kompetensi guru IPS di Tomohon dalam pembelajaran menggunakan Metode Kontekstual.

\section{SOLUSI YANG DITAWARKAN}

1. Pertama, dalam merancang pembelajaran dengan metode Kontekstual.

2. Pembimbingan dalam mengumpulkan data sesuai rumusan masalah dalam mengembangkan metode kontekstual.

3. pelatihan dalam menggunakan metode konsteksual. Kegiatan pelatihan ini meliputi penjelasan mengenai penggunaan metode ini.

4. Keempat, pelatihan dalam menganalisis dan menginterpretasi data penelitian.

5. Kelima, pelatihan dalam membuat artikel ilmiah. Luaran yang diharapkan adalah para guru memahami dan bisa membuat artikel ilmiah ilmiah. 


\section{METODE PELAKSANAAN}

\section{Metode Pelaksanaan}

Dalam rangka pengumpulan data maka dilakukan kontak langsung (face to face) dengan responden agar dapat mengamati prilaku, pendapat, sikap dan pendayagunaannya berdasarkan pandangan subjek peneliti. Dengan demikian penelitian yang bersikap deskriptif lebih mementingkan proses dari pada hasil, membatasi studi focus, memilih seperangkat criteria untuk memeriksa keabsahan data. Sasaran penelitian diarahkan kepada usaha menemukan teori-teori dasar, responden dapat menilai kembali data dan informasi yang diberikan apakah perlu direvisi atau untuk melengkapi data atau informasi baru.

Dalam ini bertujuan untuk melihat gambaran persentase guru IPS di kota Tomohon yang menggunakan pendekatan metode pembelajaran kontekstual, dan bagaimana mutu pembelajaran kontekstual dari sekolahsekolah tersebut mulai dari perencanaan, pelaksanaan, dan penilaian proses pembelajaran. Dalam menggambarkan fenomena digunakan frekwensi penggunaan pembelajaran kontekstual hasilnya dicantumkan dalam tabel-tabel frekwensi. Singarimbun dan Effendi menuliskan: "Penelitian deskriptif biasanya untuk mengetahui frekwensi terjadinya suatu aspek fenomena sosial tertentu,.... hasilnya dicantumkan dalam table-tabel frekwensi". Luaran yang diharapkan dapat terwujud dari kegiatan ini adalah: (1) Merancang pembelajaran IPS berbasis Metode pembelajaran Kontekstual (2) Penggunaan Metode Kontekstual sebagai media dalam pembelajaran IPS, dan (3) Peningkatan kompetensi guru IPS di Tomohon dalam pembelajaran menggunakan Metode Kontekstual.

Metode yang dilakukan dalam mengatasi permasalah-permasalahan guru tersebut adalah dengan memberikan pelatihan atau training, bimbingan, dan pendampingan kepada para guru. Pelatihan dilakukan dengan melakukan pertemuan secara langsung melalui tatap muka (face to face) dengan para guru.

Kegiatan pelatihan, bimbingan, dan pendampingan dilakukan melalui 3 langkah:

1. Pertama, pelatihan, pembimbingan, dan pendampingan dalam merancang pembelajaran dengan metode Kontekstual. Luaran yang diinginkan adalah para guru memahami, menguasai, dan terampil dalam merancang metode ini.

2. Kedua, pelatihan, pembimbingan, dan pendampingan dalam mengumpulkan data sesuai rumusan masalah dalam mengembangkan metode kontekstual. Luaran yang diinginkan dari kegiatan 
ini adalah para guru memahami, menguasai, dan terampil dalam membuat instrumen penelitian.

3. Ketiga, pelatihan dalam menggunakan metode konsteksual. Kegiatan pelatihan ini meliputi penjelasan mengenai penggunaan metode ini.

4. Keempat, pelatihan dalam menganalisis dan menginterpretasi data penelitian. Luaran yang diinginkan dari kegiatan ini adalah para guru memahami, dan bisa menganalisis hasil output dalam penggunaan metode kontekstual serta menginterpretasikkanya untuk bisa membuktikan hipotesis apa yang diterima sehingga bisa diambil kesimpulan dari hasil output itu.

5. Kelima, pelatihan dalam membuat artikel ilmiah. Luaran yang diharapkan adalah para guru memahami dan bisa membuat artikel ilmiah ilmiah.

\section{HASIL DAN PEMBAHASAN}

Gambaran Iptek

Pendekatan Kontekstual (Contextual Teaching and Learning/CTL)

Pendekatan kontekstual (Contextual Teaching and Learning/CTL) adalah konsep belajar yang membantu guru mengaitkan antara materi yang diajarkannya dengan situasi dunia nyata siswa dan mendorong siswa membuat hubungan antara pengetahuan yang dimilikinya dengan penerapannya dalam kehidupan mereka sebagai anggota keluarga dan masyarakat. Pendekatan kontekstual mempunyai 7 komponen utama yang secara singkat akan diuraikan sebagai berikut.

Komponen pertama adalah konstruktivisme (constructivism). Menurut pandangan konstruktivisme, pengetahuan tidak diberikan secara instan kepada siswa, melainkan harus dikonstruksi sendiri oleh siswa melalui keterlibatannya secara aktif dalam kegiatan pembelajaran. Dalam kegiatan pembelajaran, siswa membangun pengetahuannya setahap demi setahap, melalui langkah-langkah pembelajaran yang dirancang dengan baik oleh guru.

Komponen kedua adalah penemuan (inquiry). Penemuan merupakan bagian inti dari kegiatan pembelajaran berbasis CTL. Pengetahuan dan keterampilan yang diperoleh siswa diharapkan bukan hasil proses mengingat atau menghafal, melainkan diperoleh siswa melalui proses penemuan terbimbing. Pembelajaran dirancang sedemikian sehingga memberikan kesempatan kepada siswa untuk menemukan konsep atau pengetahuannya dengan bimbingan guru. Komponen ketiga adalah masyarakat belajar (learning community). Berdasarkan konsep ini, siswa dapat mengkonstruksi pengetahuannya dengan baik melalui interaksi sosial. Melalui interaksi sosial, seperti diskusi kelompok, pengetahuan 
siswa akan dimantapkan melalui proses diskusi.

Komponen keempat adalah bertanya (questioning). Bertanya merupakan salah satu proses bagi siswa untuk mengkonstruksi konsep atau pengetahuan. Bagi siswa, bertanya merupakan bagian penting dalam pembelajaran berbasis inquiry, yakni menggali informasi, mengkonfirmasikan apa yang sudah diketahui, dan mengarahkan perhatian pada aspek yang belum diketahui. Guru hendaknya merancang suatu pertanyaan berkualitas yang dapat merangsang kreativitas siswa dalam upaya membangun pengetahuannya. Sebaliknya, siswa harus diberikan kesempatan secara bebas untuk mengemukakan pertanyaan-pertanyaan yang akan memungkinkan mereka lebih dapat memahami konsep dengan baik.

Komponen kelima adalah pemodelan (modeling). Menurut konsep ini, pembelajaran matematika memerlukan model yang dapat ditiru. Sebagai misal, guru berperan sebagai model yang memberikan contoh cara mengoperasikan sesuatu, menyelesaikan masalah dengan metode tertentu, dan sebagainya. Dalam pembelajaran, siswa juga dapat berperan sebagai model yang memberikan contoh kepada teman sekelasnya, yakni ketika siswa berusaha memaparkan ide atau hasil diskusinya kepada teman sekelas.
Komponen keenam adalah refleksi (reflection). Refleksi adalah cara berpikir mengenai apa yang baru dipelajari. Refleksi merupakan respon siswa terhadap kejadian, aktivitas, atau pengetahuan yang telah dipelajari atau dikuasai siswa. Guru mengimplementasikan komponen ini dengan cara mereview (merangkum) bersama siswa mengenai materi pembelajaran yang telah dipelajari, juga mengenai apa yang telah dipahami maupun yang belum dipahami siswa. Komponen terakhir, ketujuh, adalah penilaian yang sebenarnya (authentic assesment), yakni proses pengumpulan berbagai data yang dapat memberikan gambaran perkembangan belajar siswa. Data ini diambil selama kegiatan pembelajaran berlangsung, tidak hanya ketika pembelajaran selesai.

Rencana Pembelajaran Berbasis Kontekstual Dalam pembelajaran kontekstual, rencana pembelajaran (RP) diartikan sebagai rencana kegiatan guru yang berisi skenario pembelajaran tahap demi tahap mengenai halhal yang akan dilakukakan guru bersama siswa terkait topik atau pokok bahasan yang akan dipelajari demi mencapai kompetensi standar yang telah ditentukan. Dalam ini, rencana pembelajaran tidak diartikan sebagai laporan yang harus disusun dan dilaporkan kepada kepala sekolah atau pihak lain, melainkan sebagai rencana "individual" guru 
yang memuat langkah-langkah pembelajaran yang akan dilaksanakan di kelas. Rencana pembelajaran dapat difungsikan sebagai pengingat bagi guru mengenai hal-hal yang harus dipersiapkan, mengenai media apa yang akan digunakan, strategi pembelajaran yang dipilih, sistem penilaian yang akan ditentukan, dan hal-hal teknis lainnya Mengingat rencana pembelajaran lebih bersifat sebagai rencana "individual" guru, tentu tidak ada format. Memang, secara umum tidak terdapat perbedaan mendasar mengenai format rencana pembelajaran berbasis kontekstual dengan format rencana pembelajaran yang selama ini dikenal. Hal yang membedakan keduanya adalah mengenai substansi atau penekanannya. Pada pembelajaran yang secara umum dikenal, rencana pembelajaran menekankan pada deskripsi tujuan yang akan dicapai, sedangkan pada pembelajaran kontekstual lebih menekankan pada skenario pembelajarannya. Sebagaimana dikemukakan di muka bahwa pendekatan kontekstual mempunyai 7 komponen utama, maka menyusun rencana pembelajaran berbasis kontekstual berarti merancang kegiatan pembelajaran yang mengakomodasi 7 komponen utama pendekatan kontekstual tersebut.. Ketujuh komponen pendekatan kontekstual harus tersirat pada rencana pembelajaran yang disusun. Selain itu, dalam rencana pembelajaran juga dirancang bagaimana mengintegrasikan keterampilan kecakapan hidup (life skill) dalam rangkaian pembelajaran.

Berikut ini akan disajikan contoh format rencana pembelajaran berbasis kontekstual beserta penjelasan seperlunya mengenai bagian-bagiannya. Tentu saja, ini merupakan salah satu alternatif format rencana pembelajaran yang dapat diacu guru, yang tetap terbuka untuk diubah, dilengkapi, atau disesuaikan dengan kebutuhan. Secara umum rencana pembelajaran terdiri atas bagianbagian berikut.

\section{Identitas}

Identitas biasanya memuat nama mata pelajaran, satuan pendidikan, kelas/semester, dan alokasi waktu.

2. Standar kompetensi dan kopetensi standar

Bagian ini memuat standar kompetensi dan kompetensi dasar yang harus dicapai siswa melalui kegiatan pembelajaran yang dilaksanakan.

3. Indikator

4. Bagian ini memuat indikatorindikator, yakni karakteristik, ciri-ciri, perbuatan, atau respon siswa berkaitan dengan kompetensi dasar.

4. Materi pokok

Bagian ini berisi materi pokok yang dipilih sebagai sarana bagi siswa untuk mencapai kompetensi dasar yang telah 
ditetapkan. Pada bagian ini dapat pula disertai uraian singkat materi pokok.

5. Media pembelajaran.

Bagian ini menjelaskan mengenai media yang digunakan dalam kegiatan pembelajaran yang akan menunjang pencapaian standar kompetensi atau kompetensi dasar yang ditentukan.

6. Pendekatan atau metode pembelajaran

Bagian ini memuat jenis pendekatan atau metode yang dipilih atau digunakan

7. Kegiatan pembelajaran Pada bagian ini diuraikan mengenai langkah-langkah kegiatan pembelajaran, yang mengakomodasi 7 komponen pendekatan kontekstual dan pengintegrasian life skill dalam kegiatan pembelajaran. Secara umum, kegiatan pembelajaran terdiri atas 3 tahap, yakni kegiatan pendahuluan, kegiatan pokok, dan kegiatan penutup. Kegiatan pendahuluan merupakan kegiatan yang dimaksudkan untuk mengkondisikan siswa agar siap secara mental untuk mengikuti kegiatan pembelajaran. Yang termasuk dalam kegiatan ini adalah memotivasi siswa untuk mengikuti kegiatan pembelajaran, seperti memberikan contoh manfaat topik yang akan dipelajari, mengaitkan materi pelajaran dengan dunia nyata, menyampaikan standar kompetensi dan kompetensi standar yang harus dicapai siswa melalui kegiatan pembelajaran, dan langkahlangkah kegiatan pembelajaran yang akan diikuti siswa. Pada bagian ini pula dilakukan pembahasan pekerjaan rumah dan apersepsi, yakni mengaitkan materi pelajaran yang akan dipelajari siswa dengan materi pelajaran

Pada kegiatan pokok diuraikan mengenai langkah-langkah pembelajaran yang merupakan tahapan bagi siswa untuk mengkonstruksi konsep atau pengetahuan. Pada bagian ini tercermin implementasi ketujuh komponen utama pendekatan kontekstual dan pengintegrasian life skill. Sedangkan pada bagian penutup diuraikan mengenai bimbingan guru kepada siswa untuk mereview (merangkum) materi atau topik yang telah dipelajari, pemberian tugas, dan penginformasian mengenai topik atau materi pelajaran pada pertemuan berikutnya.

8. Penilaian

Pada bagian ini diuraikan mengenai jenis dan bentuk instrumen yang digunakan untuk mengukur 
ketercapaian indikator yang telah ditentukan.

\section{HASIL KEGIATAN}

\section{Perencanaan}

Kegiatan-kegiatan yang dilakukan pada tahap perencanaan adalah sebagai berikut.

Pemberitahuan pada sekolah mitra yang akan dijadikan lokasi pengabdian dan Dinas Pendidikan terkait. Pelaksanaan tahap ini didahului dengan mengirim surat pemberitahuan kepada pihak sekolah dan dinas pendidikan terkait. Setelah itu dilakukan koordinasi untuk membahas teknis pelaksanaan kegiatan.

(2)

Sosialisasi $\begin{aligned} & \text { program } \\ & \text { Sosialisasi dengan melakukan }\end{aligned}$
koordinasi dan menyampaikan
pemberitahuan secara tertulis kepada
sekolah-sekolah SMP/MTs yang
terdapat di Kota Tomohon.

Penyusunan program pelatihan Berdasarkan hasil identifikasi, hasil analisis permasalahan yang ada, hasil analisis kebutuhan, dan hasil analisis potensi sekolah, selanjutnya disusun program pelatihan.

\section{Pelaksanaan}

Tindakan dalam kegiatan ini berupa implementasi Program. Kegiatan-kegiatan yang dilakukan dalam implementasi program adalah sebagai berikut:

1. Pertama, pelatihan, pembimbingan, dan pendampingan dalam merancang pembelajaran dengan metode Kontekstual. Luaran yang diinginkan adalah para guru memahami, menguasai, dan terampil dalam merancang metode ini.

2. Kedua, pelatihan, pembimbingan, dan pendampingan dalam mengumpulkan data sesuai rumusan masalah dalam mengembangkan metode kontekstual. Luaran yang diinginkan dari kegiatan ini adalah para guru memahami, menguasai, dan terampil dalam membuat instrumen penelitian.

3. Ketiga, pelatihan dalam menggunakan metode konsteksual. Kegiatan pelatihan ini meliputi penjelasan mengenai penggunaan metode ini.

4. Keempat, pelatihan dalam menganalisis dan menginterpretasi data penelitian. Luaran yang diinginkan dari kegiatan ini adalah para guru memahami, dan bisa menganalisis hasil output dalam penggunaan metode kontekstual serta menginterpretasikkanya untuk bisa membuktikan hipotesis apa yang diterima sehingga bisa diambil kesimpulan dari hasil output itu. 
5. Kelima, pelatihan dalam membuat artikel ilmiah. Luaran yang diharapkan adalah para guru memahami dan bisa membuat artikel ilmiah ilmiah.

Dari hasil Pendampingan dari kegiatan diatas ternyata masih sedikit guru yang melaksanakannya. Rata-rata guru melakukan kegiatan ceramah, siswa membaca atau merangkum materi dari buku paket. Kebanyakan proses pembelajaran yang dilakukan guru tidak sesuai dengan skenario yang ada di RPP (rencana pelaksanaan pembelajaran). Setelah pelatihan dan pembimbingan metode Kontekstual yang dibuat guru ternyata hampir semua guru di Kota Tomohon hasil dari copy paste dari guru IPS lain, dan tidak pernah dimodifikasi atau disesuaikan dengan kondisi lingkungan dan kemampuan siswa dari sekolah tersebut. Akibat dari kondisi ini maka proses pembelajaran di sekolah tersebut menjadi monoton, dimana guru aktif mentransfer ilmu sedangkan siswa pasif hanya menerima informasi dari guru mata pelajaran IPS. Guru lebih banyak menggunakan komunikasi verbal dan sangat kurang memanfaatkan alat atau media pembelajaran IPS.

Kemampuan siswa menyerap suatu bidang ilmu banyak bergantung pada kemampuannya untuk memahami ucapan guru. Sebaliknya guru tidak sanggup menyatakan buah pikiran dengan jelas sehingga ia mengalami kesulitan untuk dipahami oleh peserta didik, juga tidak dapat mencapai penguasaan penuh atas bahan pembelajaran yang disampaikan

\section{KESIMPULAN}

1. Adanya peningkatan pengetahuan dan keterampilan para guru tentang pengembangan metode pembelajaran kontekstual walaupun awalnya ditemukan bahwa masih sedikit guru IPS yang mengimplementasikannya

2. Tersedianya media metode pembelajaran kontekstual.

\section{DAFTAR PUSTAKA}

[1] Irawati, S. (2005). Manajemen Keuangan. Bandung: Penerbit Pustaka.

[2] E. Mulyasa dan Purwadhi, Panduan Penulisan Karya Ilmiah, (Bandung: Universitas Islam Nusantara, 2008), hal .162

[3] Hanafiah, Konsep Dasar Penelitian Tindakan Kelas dan Model-Model Pembelajaran, (Bandung: Fakultas Keguruan Ilmu Pendidikan Universitas Islam Nusantara, 2010), hal. 41

[4] W. Sanjaya, Strategi Pembelajaran (Berorientasi Standar Proses Pendidikan) (Jakarta: Kencana Prenada Media Group, 2008), hal. 196Depdiknas. (2007). Panduan Pengembangan Pembelajaran IPA 
Jurnal ABDIMAS, Vol. 13, No. 1, April 2020

ISSN: 1979-0953 | e-ISSN: 2598-6066

Terpadu. Jakarta: Puskur, Balitbang

Depdiknas 